Aspiring to Enlightenment 


\section{Pure Land Buddhist Studies}

a publication of the Institute of Buddhist Studies at the Graduate Theological Union

\section{EDITORIAL BOARD}

Richard K. Payne

Chair, Institute of Buddhist Studies at the Graduate Theological Union

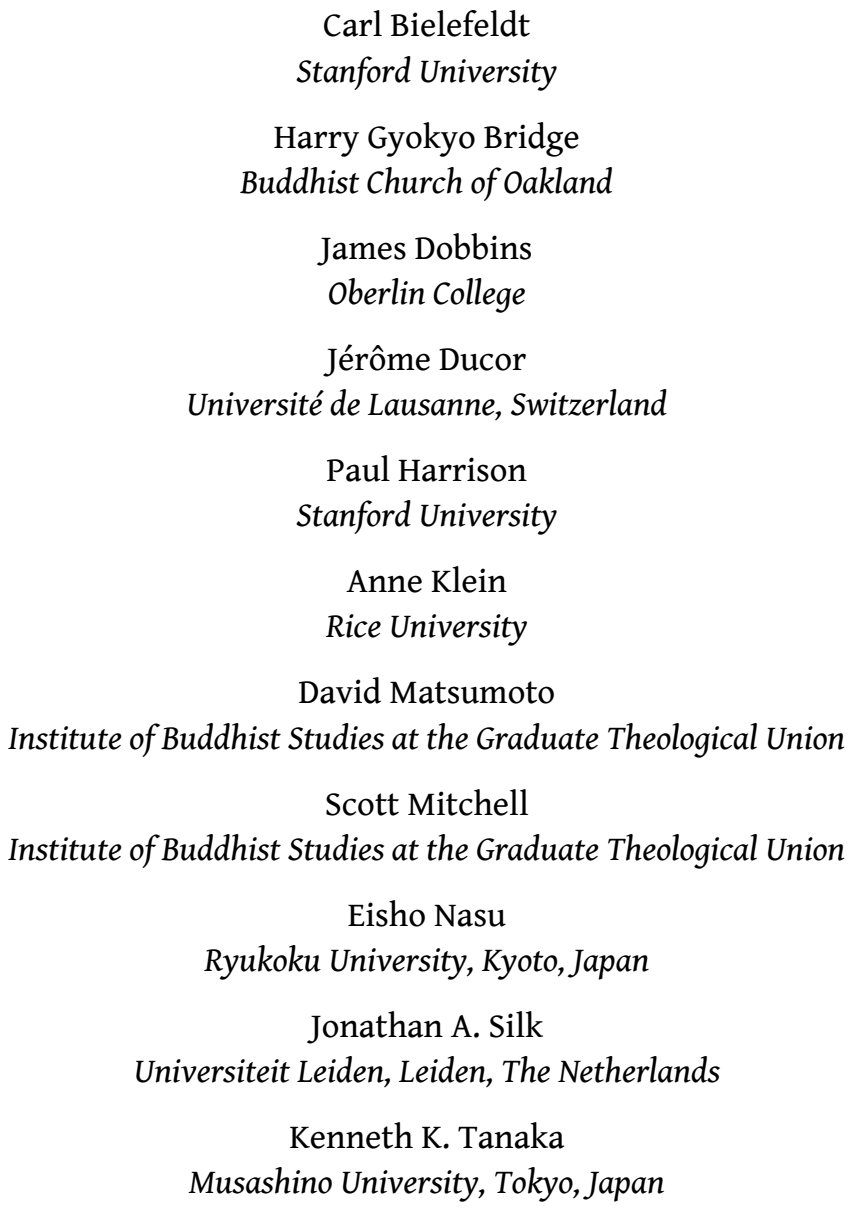




\title{
Aspiring to Enlightenment
}

Pure Land Buddhism in Silla Korea

\author{
Richard D. McBride II
}




\section{(C) 2020 University of Hawai'i Press}

All rights reserved

Printed in the United States of America

$\begin{array}{llllllllllll}25 & 24 & 23 & 22 & 21 & 20 & 6 & 5 & 4 & 3 & 2 & 1\end{array}$

\section{Library of Congress Cataloging-in-Publication Data}

Names: McBride, Richard D., II, author.

Title: Aspiring to enlightenment : Pure Land Buddhism in Silla Korea /

Richard D. McBride II.

Other titles: Pure Land Buddhist studies.

Description: Honolulu : University of Hawai'i Press, 2020. | Series: Pure

Land Buddhist studies | Includes bibliographical references and index.

Identifiers: LCCN 2020022813 | ISBN 9780824882600 (cloth) | ISBN

9780824884130 (pdf) | ISBN 9780824884154 (epub) | ISBN 9780824884147

(kindle edition)

Subjects: LCSH: 880-01 Wŏnhyo, 617-686. | Pure Land Buddhism-Silla

(Kingdom)-Doctrines. | Pure Land Buddhism-Silla (Kingdom)-Customs and

practices. | Silla (Kingdom)-Religious life and customs.

Classification: LCC BQ8518.4 .M33 2020 | DDC 294.3/92609519-dc23

LC record available at https://lccn.loc.gov/2020022813

The Pure Land Buddhist Studies series publishes scholarly works on all aspects of the Pure Land Buddhist tradition. Historically, this includes studies of the origins of the tradition in India, its transmission into a variety of religious cultures, and its continuity into the present. Methodologically, the series is committed to providing a venue for a diversity of approaches, including, but not limited to, anthropological, sociological, historical, textual, biographical, philosophical, and interpretive, as well as translations of primary and secondary works. The series will also seek to reprint important works so that they may continue to be available to the scholarly and lay communities. The series is made possible through the generosity of the Buddhist Churches of America's Fraternal Benefit Association. We wish to express our deep appreciation for its support to the Institute of Buddhist Studies.

University of Hawai'i Press books are printed on acid-free paper and meet the guidelines for permanence and durability of the Council on Library Resources.

Cover art: Detail of a seated Buddha triad, possible Amitābha, carved on the enigmatic Buddha Rock on the east side of Mt. Namsan in Kyŏngju in the early to midseventh century. Photo by author. 
In Memoriam

Younghee Yeon McBride 
